\title{
Effect of a Soil Amendment on the Survival of Ralstonia solanacearum in Different Soils
}

\author{
Vincent V. Michel and T. W. Mew
}

Entomology and Plant Pathology Division, International Rice Research Institute, Los Baños, Laguna, Philippines.

Current address of V. V. Michel: Swiss Federal Research Station for Plant Production of Changins, P.O. Box 254, CH-1260 Nyon, Switzerland. Accepted for publication 7 December 1997.

\begin{abstract}
Michel, V. V., and Mew, T. W. 1998. Effect of a soil amendment on the survival of Ralstonia solanacearum in different soils. Phytopathology 88 : 300-305.

The effect of a soil amendment (SA) composed of urea $(200 \mathrm{~kg}$ of $\mathrm{N}$ per ha) and $\mathrm{CaO}(5,000 \mathrm{~kg} / \mathrm{ha})$ on the survival of Ralstonia solanacearum in four Philippine soils was investigated in a series of laboratory experiments. Within 3 weeks after application, the SA either caused an initial decrease, a final decline, or no change in the pathogen population, depending on the particular soil type. An initial decrease occurred in a soil with a basic $\mathrm{pH}$ and resulted in a significantly $(P<0.001)$ lower pathogen population immediately and at 1 week after amending the soil. This decrease was probably due to the high $\mathrm{pH}$ in the soil during urea hydroly-

sis. A final decline in the $R$. solanacearum population after 3 weeks occurred in two soils in which nitrite accumulated after 1 week. In these soils, no decline in bacterial levels occurred when nitrite formation was inhibited by 2-chloro-6-trichloromethylpyridine. In the soil with low $\mathrm{pH}$, no nitrite accumulated and the $R$. solanacearum population did not decline. The suppressive effects of $\mathrm{pH}$ and nitrite on $R$. solanacearum growth were confirmed by in vitro experiments. Ammonium reduced the growth of $R$. solanacearum, but was not suppressive. Interactions of $\mathrm{pH}$ with ammonium and nitrite also occurred, whereby ammonium reduced growth of $R$. solanacearum only at $\mathrm{pH} 9$ and nitrite was suppressive only at $\mathrm{pH} 5$. Nitrate had no effect on $R$. solanacearum growth in vitro.
\end{abstract}

The use of soil amendments (SAs) is a widespread means to control diseases caused by soilborne plant pathogens (16). Bacterial wilt caused by Ralstonia solanacearum (formerly Burkholderia solanacearum) (39) is an important soilborne disease that affects a wide range of staple and cash crops (15). Various SAs are known to suppress bacterial wilt of tomato (Lycopersicon esculentum Mill.) $(24,25,32)$, tobacco (Nicotiana tabacum L.) (30), potato (Solanum tuberosum L.) (7,23), and banana (Musa sp.) (27). However, these studies were conducted at single sites and neglected the effect of soil type on the survival of the pathogen and the fate of the SA.

A recent four-site study in Taiwan tested the efficacy of a SA, composed of urea and calcium oxide $(\mathrm{CaO})$, in controlling bacterial wilt of tomato in the field (22). Its effects varied widely; however, in experiments in which disease control was successful, damaged tomato plants were observed in the amended plots. Such damage indicated the presence of one or several presumably phytotoxic substances in the amended soil. Ammonia or nitrite formed from the decomposition of urea in the soil may have been toxic to the plants, because similar problems have been reported in relation to the control of several fungal diseases by means of urea application $(6,21,28)$.

The goal of the current study was to determine the importance of the inorganic $\mathrm{N}$ ions produced by urea decomposition, such as ammonium, nitrite, and nitrate, in suppressing $R$. solanacearum. In laboratory studies, the effect of urea and $\mathrm{CaO}$ on the survival of this pathogen was examined in four Philippine soils. The effect of these ions on the growth of $R$. solanacearum in vitro was also determined.

Corresponding author: V. V. Michel; E-mail address: vincent.michel@rac.admin.ch

Publication no. P-1998-0205-01R

(C) 1998 The American Phytopathological Society

\section{MATERIALS AND METHODS}

Sources of $\boldsymbol{R}$. solanacearum. Three $R$. solanacearum strains (T261, T281, and T293) were obtained from the Institute of Plant Breeding at the University of the Philippines Los Baños (UPLB). All three strains were isolated from tomato and belonged to race 1 (4) and biovar 3 (14).

Sources of soil. Four soils were collected at three sites in the Philippines (Table 1). Soil BRCI was collected near Manolo Fortich (Bukidnon Province) and soil MMSU was collected at Batac (Ilocos Norte Province), two major tomato production areas of the Philippines. Soils \#19 and \#173 were collected near San Jose City (Nueva Ecija Province), located in an intensive rice-growing area. Soil types were Ultisol, Fluventic Ustropept, and Ustic Endoaquert in Bukidnon, Ilocos Norte, and Nueva Ecija, respectively. Soil samples were air-dried, sieved (1-mm mesh size), and stored at room temperature. Gravimetric water content of the soil matric potential at -0.03 MPa was determined for all soils with a pressure plate apparatus.

Inoculation of soil. Soils were infested with a 1:1:1 mixture of the three $R$. solanacearum strains. Each strain was grown on triphenyl tetrazolium chloride (TTC) agar (18) at $30^{\circ} \mathrm{C}$. After $48 \mathrm{~h}$, a suspension of each strain was prepared in sterile distilled water and adjusted to optical density at $600 \mathrm{~nm}\left(\mathrm{OD}_{600}\right)=0.3$ (approximately $6 \times 10^{8} \mathrm{CFU} / \mathrm{ml}$ ). Equal volumes of the bacterial suspensions were mixed to form the inoculum. The ratio of inoculum/soil was 1:10 (vol/vol). Soil and inoculum were mixed thoroughly, placed in polyethylene bags, and incubated at $30^{\circ} \mathrm{C}$.

Three days later, 90-ml aliquots of infested soil were placed in 250-ml beakers. Ninety milliliters corresponded to 110, 110, 100, and $110 \mathrm{~g}$ of infested soil for \#19, \#173, BRCI, and MMSU, respectively. Beakers were covered with aluminum foil to avoid desiccation and placed in an incubator at $30^{\circ} \mathrm{C}$. A separate set of beakers was prepared for each sampling date.

Application of soil amendment. The SA used for the experiments was developed at the International Potato Center (CIP) in 
Peru to control bacterial wilt of potato (7). The amounts were $435 \mathrm{~kg}$ of urea per ha $(=200 \mathrm{~kg}$ of $\mathrm{N})$ and $5,000 \mathrm{~kg}$ of $\mathrm{CaO}$ per ha (quicklime). For the laboratory experiments, weight/surface was converted to weight/volume based on the following assumption: after incorporation in the field, a layer of $20 \mathrm{~cm}$ will be mixed with SA. Therefore, the SA added to 1 ha will affect a volume of $2 \times 10^{6}$ liters $\left(10,000 \mathrm{~m}^{2}[=1 \mathrm{ha}] \times 0.2 \mathrm{~m} \times 1,000 \mathrm{liters} / \mathrm{m}^{3}\right)$ of soil. Based on this conversion, $19.5 \mathrm{mg}$ of urea $(=9 \mathrm{mg}$ of $\mathrm{N})$ and $225 \mathrm{mg}$ of $\mathrm{CaO}$ were the amounts applied to $90 \mathrm{ml}$ of soil. Two days after placing the infested soil in beakers, reagent grade urea and $\mathrm{CaO}$ were added and mixed thoroughly with the soil. Soil moisture was adjusted to $-0.03 \mathrm{MPa}$ by adding distilled water, and moisture losses were corrected at weekly intervals.

Application of nitrification inhibitor. The nitrification inhibitor 2-chloro-6-trichloromethylpyridine (10) is toxic to Nitrosomonas spp. The action of these soil microorganisms, which oxidize ammonium to nitrite, is thereby inhibited and ammonium is accumulated in the soil. Reagent grade inhibitor (Sigma Chemical Co., St. Louis) was added at weekly intervals as a $0.01 \mathrm{M}$ solution to give a final concentration of $10 \mathrm{mg} / \mathrm{kg}$ of infested soil (21), starting immediately before adding the SA. Control treatments without SA were also treated with the inhibitor.

Determination of $R$. solanacearum population, $\mathrm{pH}$, and inorganic $\mathbf{N}$. The $R$. solanacearum population, $\mathrm{pH}$, ammonium-N $\left(\mathrm{NH}_{4}{ }^{+} \mathrm{N}\right)$, nitrite- $\mathrm{N}\left(\mathrm{NO}_{2}{ }^{-} \mathrm{N}\right)$, and nitrate- $\mathrm{N}\left(\mathrm{NO}_{3}{ }^{-} \mathrm{-}\right)$ concentrations were measured three times, at 0 ( 1 to $2 \mathrm{~h}$ ), 1 , or 3 weeks following the SA application. The pathogen population was also measured 3 days after infestation of the soils, i.e., just before being placed in beakers.

For the enumeration of $R$. solanacearum in soil, a 1:9 (wt/vol) soil/sterile distilled water extract was prepared, serial dilutions were made, and then aliquots were spread on modified SM-1 medium (34). The plates were incubated at $30^{\circ} \mathrm{C}$, and typical mucoid colonies with white or pink centers were counted after 2 to 3 days.

Soil $\mathrm{pH}$ was determined in a 1:2.5 (wt/vol) air-dried soil/0.01 M $\mathrm{CaCl}_{2}$ extract (1). After sedimentation of the soil, the $\mathrm{pH}$ was measured in the clear extract with a glass electrode.

An ammonia electrode (2) was used to measure ammonium in a 1:1.5 (wt/vol) soil//0.01 $\mathrm{M} \mathrm{CaCl}_{2}$ extract. Nitrite and nitrate were analyzed in a single $1: 1.5(\mathrm{wt} / \mathrm{vol})$ soil/deionized water extract using high-performance liquid chromatography (8). The $\mathrm{pH}$ of the extracts was adjusted to below 6.5 with $5 \mathrm{~N} \mathrm{H}_{2} \mathrm{SO}_{4}$. Extracts were stored at $4^{\circ} \mathrm{C}$ until analysis.

In vitro experiments. To measure the effect of $\mathrm{pH}$ on growth of $R$. solanacearum in vitro, $100-\mathrm{ml}$ aliquots of broth $(0.1 \%$ casein hydrolysate, $1 \%$ peptone, and $0.5 \%$ glucose) in 250-ml Erlen-

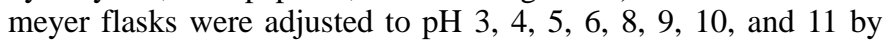
adding $5 \mathrm{~N} \mathrm{NaOH}$ or $5 \mathrm{~N} \mathrm{H}_{2} \mathrm{SO}_{4}$ after autoclaving. Nonadjusted broth at $\mathrm{pH} 7$ served as a control treatment. The effect of inorganic $\mathrm{N}$ on the in vitro growth of $R$. solanacearum was measured at three $\mathrm{pH}$ levels. Treatments at concentrations of 5, 50, and $500 \mathrm{ppm}(\mathrm{wt} / \mathrm{vol})$ of ammonium, nitrite, and nitrate were prepared using reagent grade $\mathrm{NH}_{4}\left(\mathrm{SO}_{4}\right)_{2}, \mathrm{NaNO}_{2}$, and $\mathrm{NaNO}_{3}$, respectively. Before addition to broth with $\mathrm{pH}$ of 5, 7, and 9, stock solutions of these salts were filter-sterilized $(0.2-\mu \mathrm{m}$ pore size). For each $\mathrm{pH}$ level, broths without inorganic $\mathrm{N}$ served as a control treatment. An additional control treatment was included in each in vitro experiment to measure the influence of the salt concentration (measured as electric conductivity [EC]) on growth of $R$. solanacearum. Therefore, $1 \mathrm{~N} \mathrm{Na}_{2} \mathrm{SO}_{4}$ was added to broth until the $\mathrm{EC}$ value was higher than in any other treatment.

Each of the three strains of $R$. solanacearum was tested separately. The strains were grown on TTC agar plates for $24 \mathrm{~h}$ at $30^{\circ} \mathrm{C}$. A bacterial suspension was formed by adding $10 \mathrm{ml}$ of sterile distilled water per plate. Each $100 \mathrm{ml}$ of broth culture was inoculated with $1 \mathrm{ml}$ of suspension and incubated for $6 \mathrm{~h}$ on a rotary shaker $(160 \mathrm{rpm})$ in an air-conditioned laboratory with a temperature ranging from 25 to $28^{\circ} \mathrm{C}$. Ten-milliliter culture samples were taken immediately after incubation and $6 \mathrm{~h}$ later to determine the number of $R$. solanacearum and $\mathrm{pH}$. The number of bacteria was measured immediately after sampling, and $\mathrm{pH}$ was measured on the same day or 1 day later (samples stored at $4^{\circ} \mathrm{C}$ ). The number of $R$. solanacearum was determined by measuring $\mathrm{OD}_{600}$ in absorption mode with a spectrophotometer. The correlation between $\mathrm{OD}_{600}$ and the number of CFU per milliliter was determined by dilution-plating prior to the experiments. When no increase of $\mathrm{OD}_{600}$ occurred, $\mathrm{CFU}$ per milliliter was measured by dilution plating on TTC. The $\mathrm{pH}$ was measured directly in the broth with a glass electrode.

Statistical analysis. The number of CFU per gram of dry soil and CFU per milliliter was transformed $\left(\log _{10}[x+1]\right)$ for statistical analysis (31). For the soil experiments, each treatment was replicated three times and the experiments were repeated once. Analysis of variance (ANOVA) using JMP software (SAS Institute, Cary, NC) was completed for each sampling date, and differences of pathogen population, $\mathrm{pH}$, and inorganic $\mathrm{N}$ concentrations between amended and nonamended treatments were tested for each soil separately, using linear contrasts (33). For the in vitro experiments, each treatment was replicated three times. Growth was defined as the difference in the number of $R$. solanacearum CFU per milliliter before and after the 6-h incubation. The growth was subjected to ANOVA and each treatment was tested against the control using linear contrasts. In the case of no significant difference, growth of $R$. solanacearum was classified as normal. When growth occurred but was significantly lower than that of the control, it was classified as reduced. In the case of no growth, it was classified as suppressed.

\section{RESULTS}

Soil experiment. In the first series of experiments, the effect of the $\mathrm{SA}$ (urea and $\mathrm{CaO}$ ) on $\mathrm{R}$. solanacearum population, $\mathrm{pH}$, and inorganic $\mathrm{N}$ concentrations was measured in four soils designated $\# 19$, \#173, BRCI, and MMSU. The average $R$. solanacearum population over all experiments in infested soil before adding the SA was $7.08 \times 10^{6}, 3.16 \times 10^{6}, 1.32 \times 10^{7}$, and $1.32 \times 10^{5} \mathrm{CFU} / \mathrm{g}$ of dry soil for soils \#19, \#173, BRCI, and MMSU, respectively. Based on ANOVA and separation of means by the least significant difference (LSD) test $(P<0.05)$, populations in \#19, \#173, and BRCI were significantly higher than in MMSU.

In MMSU, the population in the amended treatment was significantly $(P<0.001)$ lower than that in the nonamended treatment at the first two sampling dates (Fig. 1). However, at 3 weeks after amending, the difference was no longer significant. The population levels in \#19 and \#173 were marked by a significant $(P<$ $0.001)$ decline in the amended treatment at the end of the experiments. In BRCI, amending the soil did not significantly affect the $R$. solanacearum population at any time.

TABLE 1. Properties of four soils collected in three provinces in the Philippines: \#19 and \#173 from Nueva Ecija, BRCI from Bukidnon, and MMSU from Ilocos Norte

\begin{tabular}{lrrrrr}
\hline & & \multicolumn{4}{c}{ Soil designation } \\
\cline { 4 - 6 } Soil property & Unit & $\# 19$ & $\# 173$ & BRCI & MMSU \\
\hline Clay & $\mathrm{kg} / \mathrm{kg}$ & 0.26 & 0.34 & 0.59 & 0.53 \\
Silt & $\mathrm{kg} / \mathrm{kg}$ & 0.36 & 0.32 & 0.25 & 0.33 \\
Sand & $\mathrm{kg} / \mathrm{kg}$ & 0.38 & 0.34 & 0.16 & 0.14 \\
$\mathrm{pH}\left(\mathrm{H}_{2} \mathrm{O}, 1: 1\right)$ & & 5.1 & 6.7 & 6.1 & 8.1 \\
Electric conductivity $(1: 1)$ & $\mathrm{dS} / \mathrm{m}$ & 0.1 & 0.5 & 0.2 & 0.3 \\
$\mathrm{C}($ Walkley-Black) & $\mathrm{g} / \mathrm{kg}$ & 8.2 & 6.5 & 19.5 & 5.9 \\
Kjeldahl N & $\mathrm{g} / \mathrm{kg}$ & 0.7 & 0.6 & 2.1 & 0.7 \\
Exchange Ca & $\mathrm{cmol} / \mathrm{kg}$ & 4.9 & 9.7 & 3.7 & 34.6 \\
Cation exchange capacity & $\mathrm{cmol} / \mathrm{kg}$ & 9.3 & 18.3 & 12.9 & 45.2 \\
Gravimetric water content & & & & & \\
\multicolumn{1}{c}{ at $-0.03 \mathrm{MPa}$} & $\mathrm{kg} / \mathrm{kg}$ & 0.335 & 0.350 & 0.510 & 0.540 \\
\hline
\end{tabular}


Adding a SA generally led to a significant $(P<0.001) \mathrm{pH}$ increase (Fig. 1). One exception was MMSU soil, in which amended and nonamended treatments had the same $\mathrm{pH}$. In \#19 and \#173, the SA initially increased $\mathrm{pH}$ to above 7 , but $\mathrm{pH}$ later dropped below 7 at 1 and 3 weeks after amendment. In BRCI soil, the $\mathrm{pH}$ did not rise above 7 and stayed at the same level for the duration of the experiment.

Hydrolysis and nitrification of urea were different for each soil (Fig. 1). The high ammonium concentrations at the first two sampling dates indicated rapid urea hydrolysis. Further ammonium

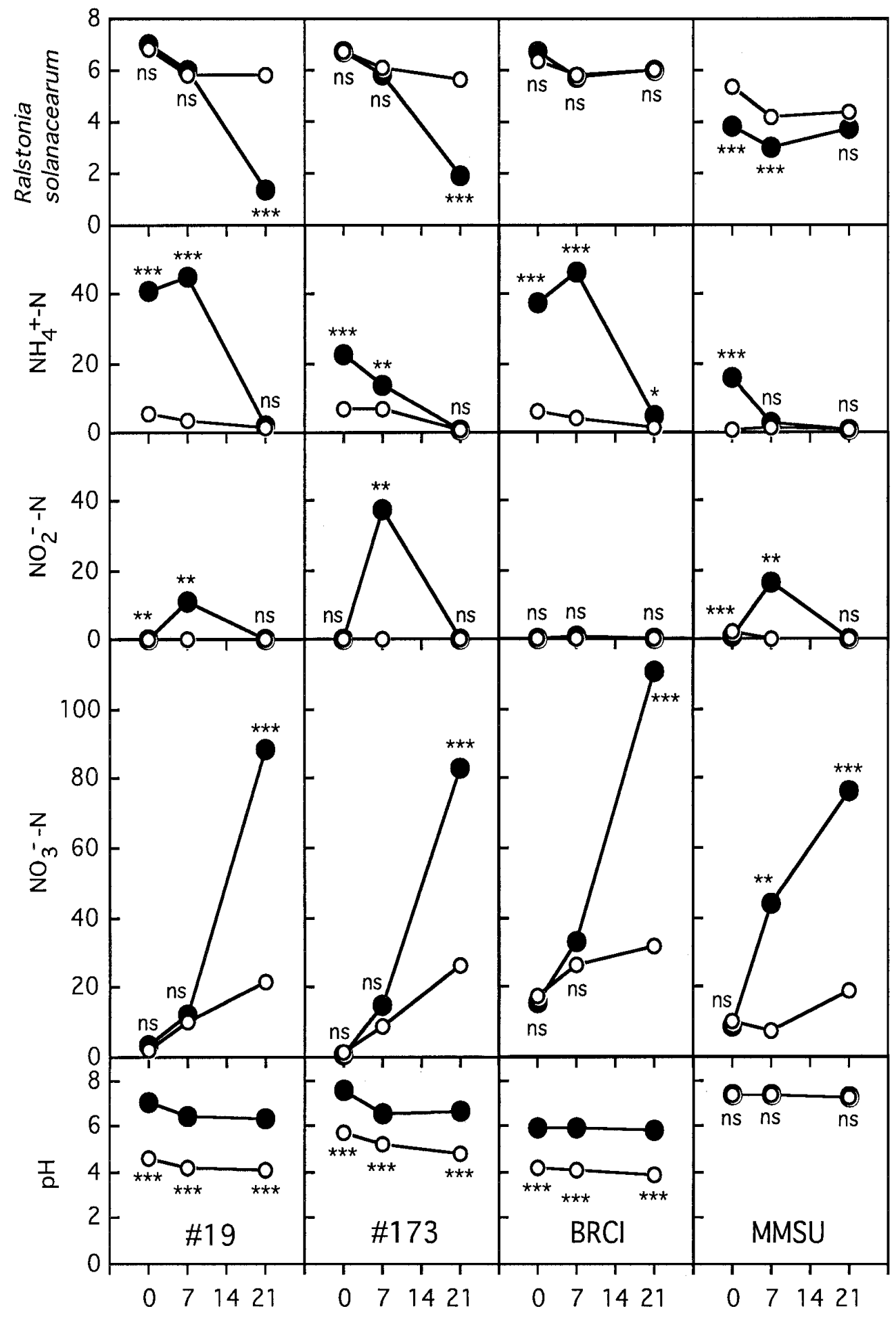

Days after adding soil amendment

Fig. 1. Populations of Ralstonia solanacearum (expressed as $\log _{10}\left[(\mathrm{CFU} / \mathrm{g}\right.$ of dry soil) +1$]$ ), concentrations of ammonium- $\mathrm{N}\left(\mathrm{NH}_{4}{ }^{+}-\mathrm{N}\right)$, nitrite- $\mathrm{N}$ $\left(\mathrm{NO}_{2}{ }^{-} \mathrm{N}\right)$, and nitrate- $\mathrm{N}\left(\mathrm{NO}_{3}{ }^{-} \mathrm{N}\right.$; expressed as $\mathrm{mg}$ of $\mathrm{N} / \mathrm{kg}$ of dry soil), and $\mathrm{pH}$ in four Philippine soils at 0 , 7, and 21 days after adding a soil amendment (SA). Data are means of two experiments. For each soil, the difference between treatment with SA ( $-\longrightarrow)$ and that without SA ( $\longrightarrow-\mathrm{O}_{-}$ was tested using linear contrasts. The highest level of significance that occurred in both experiments is indicated as follows: ns $=$ no significant difference; *,**, and $* * *=$ significant difference at $P<0.05, P<0.01$, and $P<0.001$, respectively. Soil moisture was maintained at -0.03 MPa matric potential. Soils were incubated at $30^{\circ} \mathrm{C}$. 
nitrification was reflected by the low ammonium and high nitrate concentrations at the last sampling date. One week after amending, nitrite accumulation occurred in soils \#19, \#173, and MMSU, but no nitrite was detected 2 weeks later.

Soil experiment with nitrification inhibitor. In the second series of soil experiments, the effect of the SA on $R$. solanacearum population, $\mathrm{pH}$, and inorganic $\mathrm{N}$ concentrations was measured in soils \#19 ad \#173 after application of the nitrification inhibitor. The $R$. solanacearum population did not decline significantly in the amended treatments of both soils (Fig. 2). The high concentration of ammonium and the very low concentration of nitrate 3 weeks after adding SA indicated a nearly complete inhibition of ammonium oxidation (Fig. 2). No nitrite was detected at any sampling date.

In vitro experiments. Growth of all strains was suppressed at $\mathrm{pH} 3,10$, and 11 , and strongly reduced at $\mathrm{pH} 4$ and $9(P<0.001)$. At $\mathrm{pH} 5$ and 8, growth reduction was weak or it did not occur at all. Normal growth of all strains occurred at pH 6 .

Nitrite was the inorganic $\mathrm{N}$ form that most affected the growth of $R$. solanacearum. It suppressed growth of all strains at concentrations of 500 and $50 \mathrm{ppm}$ at $\mathrm{pH} 5$. At $\mathrm{pH} \mathrm{7,} \mathrm{a} \mathrm{concentration} \mathrm{of}$ $500 \mathrm{ppm}$ reduced growth of all strains, whereas no effect occurred at $\mathrm{pH}$ 9. Growth of all strains was reduced by $500 \mathrm{ppm}$ of ammonium at $\mathrm{pH}$ 9. Growth was not affected by any other $\mathrm{pH}$-nitrite or $\mathrm{pH}$-ammonium combination. No effect of nitrate on growth of $R$. solanacearum was observed.

In all experiments, no difference was observed between the growth of $R$. solanacearum in the control broth with high EC and growth in standard control broth (data not shown).

\section{DISCUSSION}

Depending on the soil, adding the SA had different effects on the $R$. solanacearum population dynamics (Fig. 1). An initial decrease of the pathogen population occurred in MMSU soil in contrast to a final decline in soils \#19 and \#173. No effect of the SA on the $R$. solanacearum population was measured in BRCI soil. The decline of the pathogen population in the amended treatments of soils \#19 and \#173 coincided with the appearance of nitrite. In both soils, nitrite was accumulated 1 week after adding the SA, and the decline of $R$. solanacearum took place only after that time. Furthermore, the SA had no effect in these soils when nitrite accumulation was blocked by adding a nitrification inhibitor (Fig. 2). In similar studies, the declines of Fusarium oxysporum f. sp. dianthi (21) and $F$. oxysporum f. cubense (28) after urea soil application were related to nitrite accumulation. Nitrite has been reported to be at least partly responsible for the decline of several soilborne pathogens or nematodes $(29,36,40)$.

In contrast to soils \#19 and \#173, the occurrence of nitrite in MMSU soil 1 week after adding the SA did not lead to a decrease in pathogen population at 3 weeks. The in vitro experiments measuring the direct influence of nitrite showed an interaction between nitrite concentration and $\mathrm{pH}$. An increase in nitrite toxicity due to a decrease in $\mathrm{pH}$ has been reported for microorganisms in general (38). Nitrous acid, the nonionized form of nitrite, has been reported to be primarily responsible for the suppressive effect on Phytophthora spp. (35). The degree of ionization is $\mathrm{pH}$-dependent and hence the portion of nitrous acid increases at low $\mathrm{pH}$. This could explain the different effect of nitrite in our soils tested. In soils \#19 and \#173, after an initial basic value, the $\mathrm{pH}$ dropped below 7, thereby increasing the toxicity of nitrite. In soil MMSU, the $\mathrm{pH}$ stayed above 7 during the whole experiment, which might have reduced the toxic effect of nitrite in this soil.

The toxicity of ammonia to living organisms has been documented (37). The ratio of ammonia/ammonium is $\mathrm{pH}$-dependent, with ammonia comprising about 1 and $10 \%$ at $\mathrm{pH} 7.3$ and 8.3 , respectively (19). Ammonia, the nonionized form, was reported to be more important for the inhibition of Phytophthora spp. (35). In our study, ammonia was most probably not responsible for the decrease in $R$. solanacearum populations in the soil. Relatively high initial concentrations of ammonium occurred in all soils (Fig. 1 ), but a decrease in pathogen population at the beginning of the experiment only occurred in MMSU soil, which had the lowest initial ammonium concentration. Furthermore, in soils \#19 and 173 , no decrease in the $R$. solanacearum population was observed when ammonium concentrations were maintained during the en-

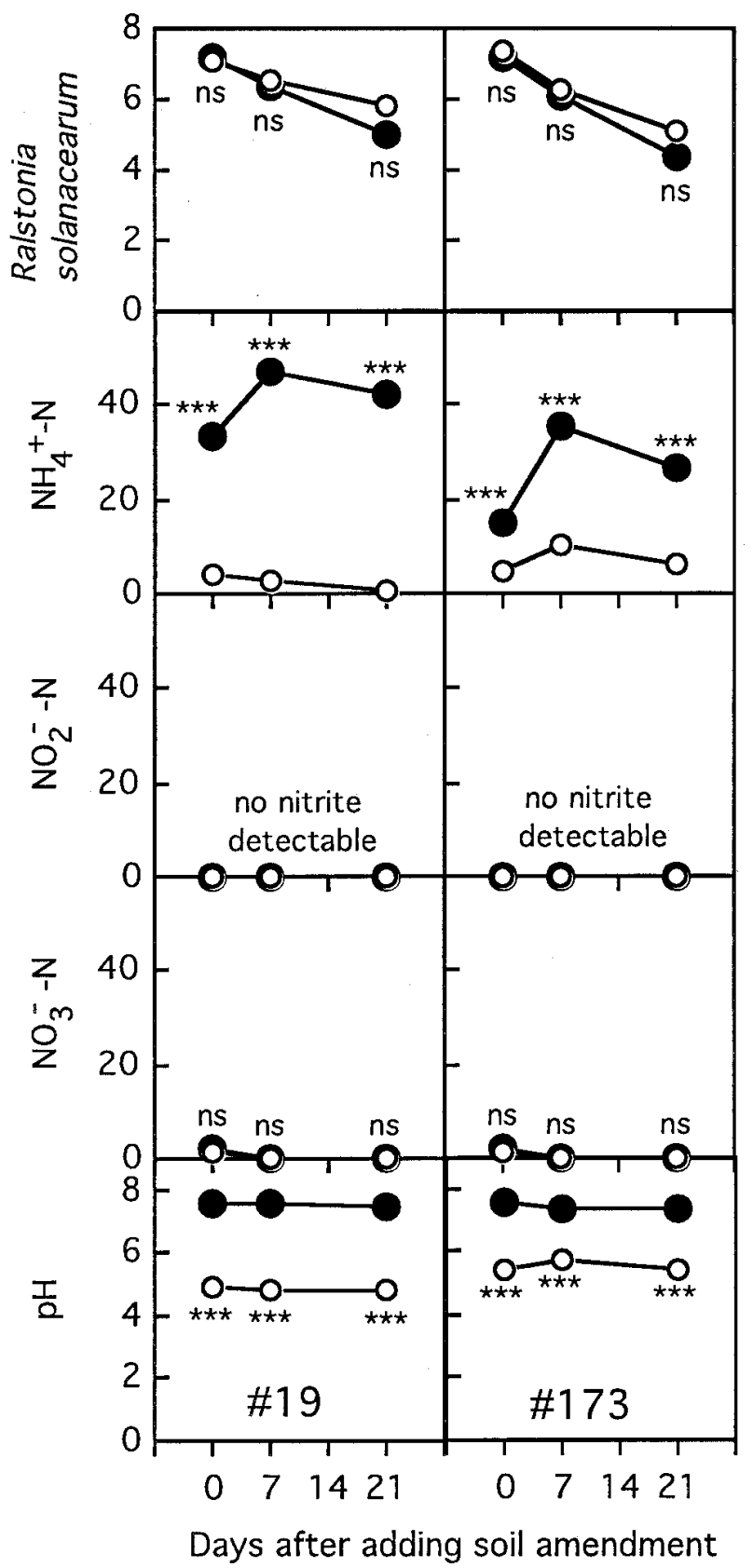

Fig. 2. Populations of Ralstonia solanacearum (expressed as $\log _{10}[(\mathrm{CFU} / \mathrm{g}$ of dry soil $)+1]$ ), concentrations of ammonium- $\mathrm{N}\left(\mathrm{NH}_{4}{ }^{+}-\mathrm{N}\right)$, nitrite- $\mathrm{N}\left(\mathrm{NO}_{2}{ }^{-}\right.$ $\mathrm{N})$, and nitrate- $\mathrm{N}\left(\mathrm{NO}_{3}{ }^{-} \mathrm{N}\right.$; expressed as $\mathrm{mg}$ of $\mathrm{N} / \mathrm{kg}$ of dry soil), and $\mathrm{pH}$ in two Philippine soils at 0,7 , and 21 days after adding a soil amendment (SA) and a nitrification inhibitor (2-chloro-6-trichloromethylpyridine). Data are means of two experiments with the exception of ammonium, nitrite, nitrate, and $\mathrm{pH}$ of the nonamended treatment, which was determined only once. For each soil, the difference between the treatment with SA (- - ) and that without SA ( $-\mathrm{O}-)$ ) was tested using linear contrasts. The highest level of significance that occurred in both experiments is indicated as follows: ns = no significant difference; $* * *$, and $* * *=$ significant difference at $P<0.05$, $P<0.01$, and $P<0.001$, respectively. Soil moisture was maintained at -0.03 $\mathrm{MPa}$ matric potential. Soils were incubated at $30^{\circ} \mathrm{C}$. 
tire experiment by use of a nitrification inhibitor (Fig. 2). In general, reduction of soil pathogens due to ammonia toxicity occurs when high concentrations of ammonia are measured $(9,26,29,40)$. In our in vitro experiments, a slight reduction in growth of $R$. solanacearum at $500 \mathrm{ppm}$ of ammonium at $\mathrm{pH} 9$ was observed. Since the soils in our study were amended with less than $0.01 \%$ of $\mathrm{N}$ (wt/wt), there was probably insufficient ammonia generated to decrease $R$. solanacearum populations.

Therefore, the initial decrease in pathogen populations observed in MMSU soil was probably due to a $\mathrm{pH}$ effect. The in vitro experiments showed that at $\mathrm{pH} \mathrm{9,} \mathrm{growth} \mathrm{of} \mathrm{all} \mathrm{three} \mathrm{bacterial} \mathrm{strains}$ was strongly reduced. During urea hydrolysis, a soil solution with $\mathrm{pH}>9$ is formed at the reaction site (12). This may have led to an important decrease in $R$. solanacearum population at the reaction sites, resulting in an average decrease in pathogen population in the whole soil volume during the first week. A pH effect would also explain the lower $R$. solanacearum population in MMSU soil compared with the three other soils before adding the SA. The $\mathrm{pH}$ of MMSU was higher than 7; when extracted with water, it became even higher than 8 (Table 1).

The absence of a SA effect on $R$. solanacearum population in BRCI soil (Fig. 1) emphasized the importance of soil type in improving the efficacy of the SA. For further application or improvement of the SA to control bacterial wilt (and other soilborne diseases and nematodes), the soil-specific fate of the SA in each soil type needs to be known. In relation to urea and $\mathrm{CaO}$ used in our study, the most important reaction seemed to be the peak of nitrite accumulation after SA application. Such accumulation can occur under different soil conditions (13). One such condition is a high concentration of ammonium at a high $\mathrm{pH}$, in which the ammonia concentration can reach a level high enough to become toxic to Nitrobacter spp., thereby inhibiting oxidation of nitrite to nitrate (12). Depending on the soil properties, the application of urea alone can generate high ammonium and $\mathrm{pH}$ conditions, which then can lead to nitrite accumulation (5). Different nitrogenous amendments (including urea) have been reported to increase populations of Nitrosomonas spp. but not of Nitrobacter spp. (25), which could lead to nitrite accumulation. The same treatments reduced or stabilized mortality in three successive tomato crops due to bacterial wilt compared with a nonamended control.

High soil temperature, an important environmental factor in the tropics, was reported to increase nitrite accumulation after urea application and to shorten the half-life of nitrite in the soil (17). The duration of nitrite accumulation is of great importance because nitrite has been reported to be phytotoxic $(3,11)$. If it is still present at transplanting, it can damage the crop. In the best case, the pathogen is more susceptible to nitrite than is the host plant. This has been reported for Phytophthora root rot of avocado (40). In the case of the host plant being as susceptible as the pathogen, a nitrite-generating SA cannot be used for disease control.

On one hand, the site specificity and the generation of phytotoxic substances such as nitrite could restrict the use of the SA tested in our study. In the case of an application or modification of the SA, the effects on the pathogen as well as on the host plant have to be studied carefully for each site. On the other hand, it is most probable that the SA can also be used to control other soilborne diseases and nematodes. In the case of a possible control of root knot nematodes (Meloidogyne spp.), which are reported to increase the incidence of bacterial wilt (20), further research would be worthwhile.

\section{ACKNOWLEDGMENTS}

This work was conducted as an IRRI-AVRDC collaborative research project and was funded by the Swiss Agency for Development and Cooperation (SDC). We thank V. Banasihan for technical assistance, M. A. Adviento and A. Dobermann for assistance in soil nitrogen analysis, N. Opina for supplying the Ralstonia solanacearum strains used in the study, and D. Johnston, A. K. Raymundo, S. Savary, and U. Schmidhalter for reviewing the manuscript.

\section{LITERATURE CITED}

1. Alef, K. 1991. Methodenhandbuch Bodenmikrobiologie: Aktivitäten, Biomasse, Differenzierung. Ecomed, Landsberg/Lech, Germany.

2. Banwart, W. L., Tabatabai, M. A., and Bremner, J. M. 1972. Determination of ammonium in soil extracts and water samples by an ammonia electrode. Comm. Soil Sci. Plant Anal. 3:449-458.

3. Bingham, F. T., Chapman, H. D., and Pugh, A. L. 1954. Solution-culture studies of nitrite toxicity to plants. Soil Sci. Soc. Am. Proc. 18:305-308.

4. Buddenhagen, I. W., Sequeira, L., and Kelman, A., 1962. Designation of races in Pseudomonas solanacearum. Phytopathology 52:726.

5. Chapman, H. D., and Liebig, G. F., Jr. 1952. Field and laboratory studies of nitrite accumulation in soils. Soil Sci. Soc. Am. Proc. 16:276-282.

6. Chun, D., and Lockwood, J. L. 1985. Reductions of Pythium ultimum, Thielaviopsis basicola, and Macrophomina phaseolina populations in soil associated with ammonia generated from urea. Plant Dis. 69:154-158.

7. Elphinstone, J. G., and Aley, P. 1993. Integrated control of bacterial wilt of potato in the warm tropics of Peru. Pages 276-283 in: Bacterial Wilt. ACIAR Proc. 45. G. L. Hartman and A. C. Hayward, eds. Australian Centre for International Agricultural Research, Canberra, Australia.

8. Gerritse, R. G. 1979. Rapid simultaneous determination of nitrate and nitrite by high-performance liquid chromatography using ultraviolet detection. J. Chromatogr. 171:527-529.

9. Gilpatrick, J. D. 1969. Role of ammonia in the control of avocado root rot with alfalfa meal soil amendment. Phytopathology 59:973-978.

10. Goring, C. A. I. 1962. Control of nitrification of ammonium fertilizers and urea by 2-chloro-6-(trichloromethyl)pyridine. Soil Sci. 93:431-439.

11. Hamilton, J. L., and Lowe, R. H. 1981. Organic matter and $\mathrm{N}$ effects on soil nitrite accumulation and resultant nitrite toxicity to tobacco transplants. Agron. J. 73:787-790.

12. Hauck, R. D. 1984. Significance of nitrogen fertilizer microsite reactions in soil. Pages 507-519 in: Nitrogen in Crop Production. R. D. Hauck, ed. Am. Soc. Agron.-Crop Sci. Soc. Am-Soil Sci. Soc. Am., Madison, WI.

13. Hauck, R. D., and Stephenson, H. F. 1965. Nitrification of nitrogen fertilizers. Effect of nitrogen source, size and $\mathrm{pH}$ of the granule, and concentration. J. Agric. Food Chem. 13:486-492.

14. Hayward, A. C. 1964. Characteristics of Pseudomonas solanacearum. J. Appl. Bacteriol. 27:265-277.

15. Hayward, A. C. 1991. Biology and epidemiology of bacterial wilt caused by Pseudomonas solanacearum. Annu. Rev. Phytopathol. 29:65-87.

16. Huang, H. C., and Huang, J. W. 1993. Prospects for control of soilborne plant pathogens by soil amendment. Curr. Topics Bot. Res. 1:223-235.

17. Huang, Y. M., and Juang, T. C. 1982. Urea transformation in upland soils of Taiwan. III. The effect of urea concentrations, soil temperatures and soil moistures on nitrogen transformation in soil. J. Agric. For. 31:91-98.

18. Kelman, A. 1954. The relationship of pathogenicity in Pseudomonas solanacearum to colony appearance on a tetrazolium medium. Phytopathology 44:693-695.

19. Kissel, D. E., Sander, D. H., and Ellis, R. 1985. Fertilizer-plant interactions in alkaline soils. Pages 153-196 in: Fertilizer Technology and Use. O. P. Engelstad, ed. Soil Sci. Soc. Am., Madison, WI.

20. Libman, G., Leach, J. G., and Adams, R. E. 1964. Role of certain plantparasitic nematodes in infection of tomatoes by Pseudomonas solanacearum. Phytopathology 54:151-153.

21. Löffler, H. J. M., Cohen, E. B., Oolbekkink, G. T., and Schippers, B. 1986. Nitrite as a factor in the decline of Fusarium oxysporum f. sp. dianthi in soil supplemented with urea or ammonium chloride. Neth. J. Plant Pathol. 92:153-162.

22. Michel, V. V., Wang, J.-F., Midmore, D. J., and Hartman, G. L. 1997. The effects of intercropping and soil amendment with urea and calcium oxide on the incidence of bacterial wilt of tomato and survival of soilborne Pseudomonas solanacearum in Taiwan. Plant Pathol. 46:600-610.

23. Nielsen, L. W., and Todd, F. A. 1945. Preliminary evaluation of some soil disinfestants for controlling Southern bacterial wilt of potatoes. Am. Potato J. 22:197-202.

24. Power, R. H. 1983. Relationship between the soil environment and tomato resistance to bacterial wilt (Pseudomonas solanacearum): 4. Control Methods. Surinaamse Landbouw 31:39-47.

25. Prior, P., and Béramis, M. 1990. Induction de la résistance au flétrissement bactérien dû à Pseudomonas solanacearum E F Smith chez un cultivar de tomate réputé sensible. Agronomie 10:391-401.

26. Rush, C. M., and Lyda, S. D. 1982. Effects of anhydrous ammonia on mycelium and sclerotia of Phymatotrichum omnivorum. Phytopathology 72:1085-1089.

27. Sequeira, L. 1958. Bacterial wilt of bananas: Dissemination of the patho- 
gen and control of the disease. Phytopathology 48:64-69.

28. Sequeira, L. 1963. Effect of urea applications on survival of Fusarium oxysporum f. cubense in soil. Phytopathology 53:332-336.

29. Smiley, R. W., Cook, R. J., and Papendick, R. I. 1970. Anhydrous ammonia as a soil fungicide against Fusarium and fungicidal activity in the ammonia retention zone. Phytopathology 60:1227-1232.

30. Smith, T. E. 1944. Control of bacterial wilt (Bacterium solanacearum) of tobacco as influenced by crop rotation and chemical treatment of the soil. Circ. 692, U.S. Dep. Agric., Washington, DC.

31. Steel, R. G. D., and Torrie, J. H. 1960. Principles and Procedures of Statistics. McGraw-Hill Book Company, New York.

32. Sun, S.-K., and Huang, J.-W. 1985. Formulated soil amendment for controlling Fusarium wilt and other soilborne diseases. Plant Dis. 69:917-920.

33. Swallow, W. H. 1984. Those overworked and oft-misused mean separation procedures-Duncan's, LSD, etc. Plant Dis. 68:919-921.

34. Tsai, J.-W., Hsu, S.-T., and Chen, L.-C. 1985. Bacteriocin-producing strains of Pseudomonas solanacearum and their effect on development of bacterial wilt of tomato. Plant Prot. Bull. (Taiwan) 27:267-278.
35. Tsao, P. H., and Oster, J. J. 1981. Relation of ammonia and nitrous acid to suppression of Phytophthora in soils amended with nitrogenous organic substances. Phytopathology 71:53-59.

36. Walker, J. T. 1971. Populations of Pratylenchus penetrans relative to decomposing nitrogenous soil amendments. J. Nematol. 3:43-49.

37. Warren, K. S. 1962. Ammonia toxicity and pH. Nature 195:47-49.

38. Wodzinski, R. S., Labeda, D. P., and Alexander, M. 1978. Effects of low concentrations of bisulfite-sulfite and nitrite on microorganisms. Appl. Environ. Microbiol. 35:718-723.

39. Yabuuchi, E., Kosako, Y., Yano, K., Hotta, H., and Nishiuchi, Y. 1995. Transfer of two Burkholderia and an Alcaligenes species to Ralstonia gen. nov.: Proposal of Ralstonia pickettii (Ralston, Palleroni and Doudoroff 1973) comb. nov., Ralstonia solanacearum (Smith 1896) comb. nov. and Ralstonia eutropha (Davis 1969) comb. nov. Microbiol. Immunol. 39:897-904.

40. Zentmyer, G. A., and Bingham, F. T. 1956. The influence of nitrite on the development of Phytophthora root rot of avocado. Phytopathology 46:121-124. 